\title{
Media informasi dan tingkat pendidikan berhubungan dengan kehamilan remaja Indonesia
}

\author{
Ayu Aminatussyadiah, ${ }^{1}$ Suci Fitriana Pramudya Wardani, ${ }^{2 *}$ \\ Amrina Nur Rohmah ${ }^{3}$ \\ 1, 2, 3 Program Magister Kebidanan, Universitas ‘Aisyiyah Yogyakarta - Indonesia
}

\begin{abstract}
In the digital era, everyone has free access to various content using an electronic device, including teenagers. Pornographic content is also easy to access. The lack of reproductive knowledge among teenagers can cause risk behavior such as unsafe sexual activity that can lead to teenage pregnancy. Teenage pregnancy is a serious problem that can be endangering every young mother's life. This condition can be a life-threatening for both mother and baby. This study aimed to determine the effect of media access and adolescent girls' educational levels on the incidence of teenage pregnancy in Indonesia. A cross-sectional design was used in this study. This study's sample was all young women contained in the 2012 IDHS data with an age range of 15-19 years old with a total sample size of 7,203 respondents. A Chi-square test was used in this study for data analysis. The results of this study show that there is a relationship between media information and the educational level of adolescent girls to the incident of teenage pregnancy in Indonesia.
\end{abstract}

Keywords: information media; education; teenage pregnancy

Pada era digital semua orang memiliki kebebasan untuk mengakses berbagai konten menggunakan alat elektronik termasuk di dalamnya anak-anak remaja. Konten yang berbau pornografi sangat mudah diakses. Apabila remaja tidak diimbangi dengan ilmu pengetahuan yang baik terutama ilmu tentang kesehatan reproduksi maka mampu menyebabkan remaja tersebut melalkukan kegiatan seksual yang tidak aman yang dapat menyebabkan kehamilan. Kehamilan pada usia remaja merupakan masalah serius yang dapat memengaruhi kehidupan seorang remaja. Selain memengaruhi ibu, kehamilan pada usia remaja juga dapat memengaruhi bayi yang dilahirkan oleh ibu yang masih berusia remaja. Tujuan dari penelitian ini adalah untuk mengetahui pengaruh akses media dan tingkat pendidikan remaja putri dengan kejadian kehamilan remaja di Indonesia. Penelitian ini merupakan penelitian kuantitatif menggunakan rancangan cross-sectional study. Penelitian ini menggunakan data sekunder. Sampel pada penelitian ini adalah seluruh remaja putri yang terdapat pada data SDKI 2012 dengan rentang usia 15-19 tahun, dan memiliki data yang lengkap, yaitu sebanyak 7.203 responden. Analisis data statistik pada penelitian ini menggunakan uji chi-square. Hasil dari penelitian ini adalah terdapat adanya hubungan media informasi maupun tingkat pendidikan remaja putri terhadap kehamilan remaja di Indonesia.

Kata Kunci: media informasi; pendidikan; kehamilan remaja

*Korespondensi Penulis: Suci Fitriana Pramudya Wardani (email: sucipramudyawardani@gmail.com), Jl. Suryowijayan Il, Gedongkiwo, Mantrijeron, Yogyakarta, 55142. 


\section{Pendahuluan}

Kehamilan dikalangan remaja disebabkan oleh berbagai faktor. Penelitian yang dilakukan Raj et al. (2010) menyebutkan bahwa faktor sosial ekonomi, rendahnya pencapaian pendidikan, struktur budaya dan keluarga semuanya secara konsisten diidentifikasi sebagai faktor risiko kehamilan remaja. Penelitian lain yang meneliti tentang faktor kelamilan remaja dilakukan oleh Honig (2012) dalam penelitiannya yang berjudul teen pregnancy menyatakan bahwa penggambaran media memengaruhi perilaku seksual remaja. Tayangan televisi dan majalah yang memiliki konten pronografi akan mendorong remaja yang untuk terlibat dalam aktivitas seksual.

Data WHO tahun 2014 secara global menyatakan bahwa sekitar 16 juta anak perempuan di dunia berusia antara 15 sampai 19 tahun dan sekitar 1 juta anak perempuan di bawah usia 15 tahun melahirkan setiap tahun. Komplikasi selama kehamilan dan persalinan adalah penyebab kematian kedua bagi gadis berusia 15-19 tahun di seluruh dunia. Setiap tahun, sekitar 3 juta anak perempuan berusia 15 sampai 19 tahun menjalani aborsi yang tidak aman. Bayi yang lahir dari ibu yang masih remaja memiliki risiko kematian yang jauh lebih tinggi daripada yang lahir dari wanita berusia 20 sampai 24 tahun (WHO, 2014).

Survei Demografi Kesehatan Indonesia (SDKI 2012) menemukan bahwa angka kehamilan remaja usia 15-19 tahun mencapai 48 dari 1.000 kehamilan. Selain itu, survei Pusat Unggulan Asuhan Terpadu Kesehatan Ibu dan Bayi yang dikutip Badan Kependudukan dan Keluarga Berencana Nasional (BKKBN) memperkirakan bahwa tiap tahun ada sekitar 2,1-2,4 juta perempuan melakukan aborsi. Sebanyak 30 persen di antaranya adalah remaja. Menurut laporan Rencana Pembangunan Jangka Menengah Nasional (RPJMN) angka kehamilan tidak diinginkan secara nasional masih tinggi yaitu 9,2 persen, belum mencapai target RPJMN 20152019 sebesar 7 persen pada tahun 2016 (BKKBN, 2016).

Kemudahan mengakses berbagai informasi menggunakan media informasi, memberi kemudahan bagi remaja untuk terpapar dengan hal-hal yang berbau pornografi. Tidak sedikit remaja yang menonton tayangan pornografi atau membaca majalah dewasa bersama teman atau pasangan sehingga mampu menimbulkan rangsangan dan memunculkan keinginan para remaja untuk melakukan atau mempraktekkan apa yang sudah dilihatnya. Remaja mulai ingin tahu tentang kehidupan seksual manusia. Untuk itu, mereka mencari informasi mengenai seks, baik melalui buku, film, atau gambar-gambar lain yang dilakukan secara sembunyi-sembunyi. Apabila remaja tidak dibekali dengan sex education maka dapat menyebabkan terjadinya kehamilan remaja (Nugraha, 2010).

Kehamilan pada usia remaja merupakan masalah serius yang dapat memengaruhi kehidupan seorang remaja. Selain memengaruhi ibu, kehamilan pada usia remaja juga dapat memengaruhi bayi yang dilahirkan oleh ibu yang masih berusia remaja. Menurut BKKBN terdapat beberapa alasan medis untuk menunda usia perkawinan pertama dan kehamilan pertama bagi istri yang belum berumur 20 tahun yaitu kondisi rahim dan panggul belum berkembang optimal sehingga dapat mengakibatkan risiko kesakitan dan kematian pada saat persalinan, nifas serta bayinya, dan kemungkinan timbulnya 
risiko medik. Resiko tinggi kehamilan remaja yang dialami ibu meliputi: keguguran, perdarahan, infeksi, anemia, kehamilan, keracunan kehamilan (gestosis), yang menimbulkan persalinan yang lama dan sulit. Risiko untuk bayi meliputi: prematuritas, berat lahir rendah (BBLR), cacat lahir, angka kematian bayi (Wijayanti, 2014).

Menurut penelitian sebelumnya dilakukan oleh Omarsari dan Djuwita (2008) dengan judul "Kehamilan Pranikah Remaja di Kabupaten Sumedang" menyatakan kehamilan pranikah remaja di Kabupaten Sumedang tinggi cukup tinggi yakni $40,5 \%$. Faktor yang berhubungan dengan kehamilan pranikah remaja meliputi usia ketika hamil, frekuensi pacaran, pola asuh orang tua, keutuhan pernikahan orang tua dan keterpaparan teman. Disarankan untuk melakukan peningkatan metoda pelayanan kesehatan reproduksi dan seksualitas dikalangan remaja, menambah jumlah kader remaja (peer educator) melalui pendidikan dan pelatihan. Meningkatkan keterlibatan orang tua mendampingi remaja melalui masa transisi kehidupan, mendirikan pusat konsultasi dan youth centre.

Kehamilan remaja juga dapat memiliki efek sosial dan ekonomi yang negatif pada anak perempuan, keluarga dan masyarakat. Banyak gadis yang hamil harus putus sekolah. Seorang gadis dengan sedikit atau tanpa pendidikan memiliki sedikit keterampilan dan kesempatan untuk mencari pekerjaan. Ini juga bisa memiliki biaya ekonomi dengan negara yang kehilangan pendapatan tahunan yang akan diperoleh seorang wanita muda seumur hidupnya, jika dia tidak hamil sejak awal (WHO, 2014).

Faktor yang mendasari terjadinya kehamilan remaja adalah kurangnya pengetahuan remaja dimana hal ini dapat diperoleh salah satunya dengan pendidikan. Menurut Undang-Undang Republik Indonesia Nomor 20 Tahun 2003 tentang Sistem Pendidikan Nasional menyebutkan bahwa pendidikan adalah usaha sadar dan terencana untuk mewujudkan suasana belajar dan proses pembelajaran agar peserta didik secara aktif mengembangkan potensi dirinya untuk memiliki kekuatan spiritual keagamaan, pengendalian diri, kepribadian, kecerdasan, akhlak mulia, serta keterampilan yang dibutuhkan bagi dirinya, masyarakat dan bangsa (Rohman, 2011).

Berdasarkan latar belakang di atas, maka peneliti tertarik untuk mengetahui pengaruh akses media dan tingkat pendidikan remaja putri dengan kejadian kehamilan remaja di Indonesia.

\section{Metode}

Penelitian ini dilakukan oleh tiga orang peneliti yang berasal dari Universitas 'Aisyiyah Yogyakarta. Penelitian ini merupakan penelitian kuantitatif dengan menggunakan rancangan cross sectional study. Perizinan terkait penelitian ini telah dilakukan di Universitas Aisyiyah Yogyakarta. Penelitian ini menggunakan data sekunder yaitu data yang berasal dari Survei Demografi dan Kesehatan Indonesia (SDKI) tahun 2012 yang dipublikasikan oleh Demographic Health Surveys (DHS) Program (2013). Sampel pada penelitian ini adalah seluruh remaja putri yang terdapat pada data SDKI 2012 dengan rentang usia 15-19 tahun, dan memiliki data yang lengkap, yaitu sebanyak 7.203 responden. Analisis data statistik pada penelitian ini menggunakan uji chi-square.

\section{Hasil dan Pembahasan}

Pada Tabel 1 dapat dilihat bahwa usia remaja didominasi oleh remaja yang berusia 16 tahun dan tinggal di daerah urban (perkotaan). Mayoritas 
Ayu Aminatussyadiah, Suci Fitriana Pramudya Wardani, Amrina Nur Rohmah

remaja yang hanya menempuh pendidikan dasar. mengakses media informasi baik koran, radio, Selain itu, masih terdapat remaja yang tidak dapat maupun televisi.

Tabel 1. Karakteristik Responden

\begin{tabular}{|c|c|c|c|}
\hline \multirow{2}{*}{ Karakteristik } & & \multicolumn{2}{|c|}{ Jumlah } \\
\hline & & $\mathrm{N}$ & $\%$ \\
\hline \multirow{5}{*}{ Usia (tahun) } & 15 tahun & 1487 & 20.6 \\
\hline & 16 tahun & 1562 & 21.7 \\
\hline & 17 tahun & 1497 & 20.8 \\
\hline & 18 tahun & 1327 & 18.4 \\
\hline & 19 tahun & 1330 & 18.5 \\
\hline \multirow[b]{2}{*}{ Tempat Tinggal } & Urban & 3700 & 51.4 \\
\hline & Rural & 3503 & 48.6 \\
\hline \multirow{4}{*}{ Education } & Tidak sekolah & 65 & 0.9 \\
\hline & Pendidikan Dasar & 3500 & 48.6 \\
\hline & Pendidikan Menengah & 3129 & 43.4 \\
\hline & Pendidikan Tinggi & 509 & 7.1 \\
\hline \multicolumn{4}{|l|}{ Akses Media } \\
\hline \multirow{3}{*}{$\begin{array}{l}\text { Koran/ } \\
\text { Majalah }\end{array}$} & Tidak sama sekali & 2564 & 35.6 \\
\hline & $\begin{array}{l}\text { Kurang dari sekali } \\
\text { seminggu }\end{array}$ & 3427 & 47.6 \\
\hline & $\begin{array}{l}\text { Seminggu minimal } \\
\text { satu kali }\end{array}$ & 1212 & 16.8 \\
\hline \multirow{3}{*}{ Radio } & Tidak sama sekali & 2514 & 34.9 \\
\hline & $\begin{array}{l}\text { Kurang dari sekali } \\
\text { seminggu }\end{array}$ & 2902 & 40.3 \\
\hline & $\begin{array}{l}\text { Seminggu minimal } \\
\text { satu kali }\end{array}$ & 1787 & 24.8 \\
\hline \multirow{3}{*}{ Televisi } & Tidak sama sekali & 228 & 3.2 \\
\hline & $\begin{array}{l}\text { Kurang dari sekali } \\
\text { seminggu }\end{array}$ & 782 & 10.9 \\
\hline & $\begin{array}{l}\text { Seminggu minimal } \\
\text { satu kali }\end{array}$ & 6193 & 86.0 \\
\hline
\end{tabular}

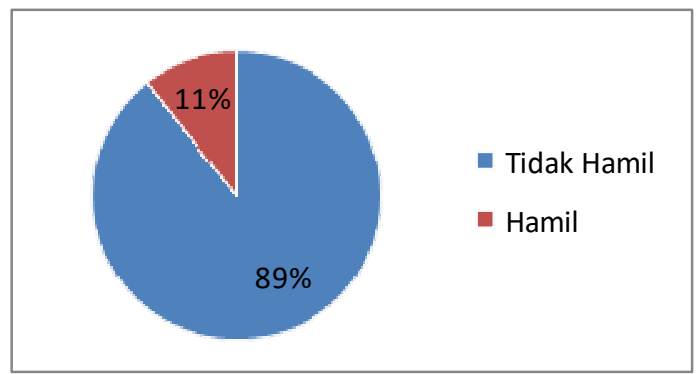

Diagram 1. Persentase Kehamilan Remaja 
Berdasarkan Diagram 1, diperoleh data bahwa sebanyak $11 \%$ remaja telah mengalami kehamilan atau sekitar 771 remaja dari jumlah keseluruhan yaitu sebesar 7.203 responden. Kehamilan remaja adalah fenomena kehidupan remaja yang dapat mengganggu kesehatan reproduksi secara fisik, mental dan sosial serta komplikasi dan kematian ibu dan bayi. Secara psikososial, remaja dapat terkucil, merasa malu, depresi, putus sekolah, sulit bekerja, miskin dan menambah pertumbuhan penduduk (Omarsari \& Djuwita, 2008).

Kehamilan pada masa remaja membawa risiko medis dan psikososial yang lebih besar, yang menimbulkan masalah dalam kesehatan masyarakat, keadilan dan pendidikan, serta risiko kematian ibu empat kali lebih tinggi pada remaja di bawah 16 tahun. Selain itu, di antara remaja berusia 15 sampai 19 tahun, kematian terkait kehamilan adalah penyebab kematian kedua setelah kecelakaan. Ibu yang lebih muda mengalami peningkatan risiko pengembangan fistula obstetrik, anemia, eklampsia, perdarahan postpartum, dan endometritis puerperal.
Selain itu, remaja yang berusia di bawah 19 tahun memiliki risiko 50\% lebih tinggi untuk kelahiran mati dan kematian neonatal, peningkatan risiko kelahiran prematur, memiliki bayi baru lahir dengan berat lahir rendah dan asfiksia. Selain memengaruhi kesehatan ibu, pernikahan dini dan persalinan juga mencegah remaja bersekolah dan melanggengkan siklus kemiskinan dan ketidaktahuan (Sámano et al., 2017).

Angka kehamilan remaja berdasarkan data demografi 2012 (Diagram 2) menyatakan bahwa mayoritas terjadi pada daerah rural atau pedesaan. Alasan hal tersebut dapat terjadi berdasarkan penelitian Sayem dan Nury (2011) bahwa keterpaparan remaja akan informasi tentang pendidikan reproduksi masih rendah di daerah pedesaan. Penelitian yang dilakukan di Florida selatan menyebutkan bahwasannya kehamilan di rural area banyak dikarenakan keadaan sosial ekonomi yang rendah serta orangtua yang berpendidikan rendah, tidak ratanya pelayanan kesehatan remaja, dan remaja yang diasuh oleh orangtua tunggal sehingga kurang pengawasan (Weiss, 2012).

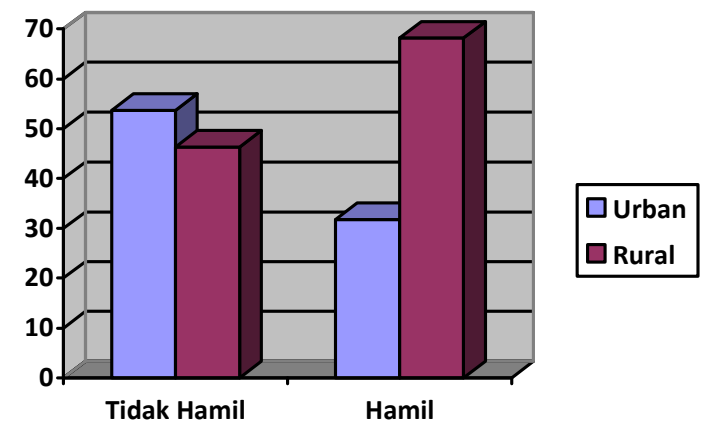

Diagram 2. Persebaran Kehamilan Remaja terhadap Tempat Tinggal 
Hal tersebut berbanding terbalik dengan penelitian yang dilakukan oleh Gallup-Black dan Weitzman (2004) di 5 kota di U.S menyebutkan bahwasanya kehamilan di perkotaan disebabkan oleh faktor diantaranya adalah lingkungan sekitar rumah dan sekolah, kurangnya pengawasan orang tua, kekerasan terhadap anak, orangtua tunggal, berhubungan seksual sebelum usia 18 tahun merupakan hal yang biasa menurut teman sebaya, menjadi orang tua di usia remaja dianggap sebagai suatu hal yang dapat diterima. Penelitian yang dilakukan di Turki menyebutkan bahwasannya terdapat 7 faktor yang menyebabkan kehamilan remaja di daerah perkotaan yaitu terjadi tindak kekerasan dalam keluarga, keluarga yang menentang perkawinan pada remaja, tingkat pendidikan yang rendah, kurangnya jaminan sosial, tinggal di sebuah rumah yang dalam 1 kamar berisi lebih dari 1 orang, perempuan yang menganggur, memiliki saudara perempuan dengan riwayat kehamilan remaja (Gökçe et al., 2007).

Media masa memiliki 2 dampak yang berbeda kepada remaja di satu sisi mampu menyebabkan remaja melakukan hal yang menyimpang dikarenakan beberapa konten negatif yang diakses remaja melalui media masa seperti konten pornografi yang mampu menyebabkan terjadinya kehamilan remaja. Namun disisi lain media massa juga mampu memberikan dampak yang bagus dalam hal pengetahuan remaja tentang kesehatan reproduksi. Telah dilakukan berbagai penelitian tentang kampanye HIV/AIDS baik memlaui siaran atau media cetak yang dilakukan di Afrika, Amerika latin, Asia pada tahun 1990-2004, kampanye HEART (Helping Each Other Act Responsibly Together) di Zambia pada tahun 1999. Evaluasi dilakukan setelah kampanye melalui media masa dilakukan, hasilnya adalah penggunaan kondom meningkat sehingga mampu menurunkan kejadian HIV/AIDS dan juga kehamilan remaja (Delgado \& Austin, 2007).

Berdasarkan hasil analisis (Diagram 3) diketahui bahwa remaja yang mengakses media massa terbanyak yaitu televisi dengan frekuensi paparan seminggu minimal satu kali berjumlah 6.193 responden dengan kejadian kehamilan

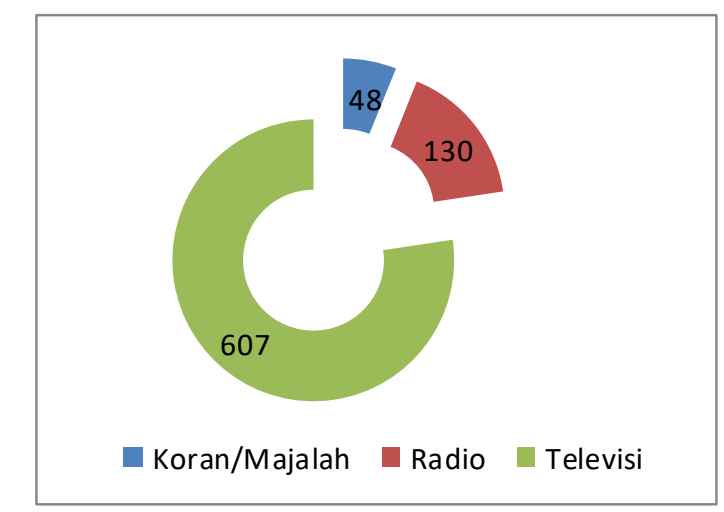

Diagram 3 Media Informasi terhadap Kehamilan Remaja 
remaja akibat paparan media televisi berjumlah sebesar 607 responden. Hasil uji chi-square dengan tingkat kepercayaan 95\%, diperoleh hasil $p<0,05 \quad(p=0,000)$ sehingga media televisi memiliki dampak yang besar dalam peningkatan kehamilan remaja.

Menurut Wallmyr dan Welin (2006) media yang paling sering digunakan remaja untuk melihat pornografi adalah internet dan televisi. Eksploitasi seksual dalam video klip dan film ternyata mendorong para remaja untuk melakukan akivitas seks secara sembarangan diusia muda. Hasil penelitian Huver et al. (2010) di Amerika menyatakan penayangan seks di televisi telah mempengaruhi perilaku seks remaja, dengan data sebanyak $20 \%$ remaja usia 17 tahun telah melakukan intercourse, $40 \%$ remaja usia 17 tahun mulai meraba payudara dan terdapat $20 \%$ remaja usia 17 tahun meraba genitalia. Dengan kata lain perilaku seksual berisikoinilah yang akan berdampak pada kehamilan tidak diinginkan pada remaja. Honig (2012) dalam penelitiannya yang berjudul teen pregnancy menyatakan bahwa penggambaran media memengaruhi perilaku seksual remaja. Tayangan televisi dan majalah terkenal yang memberitakan tentang remaja yang hamil akan memengaruhi pembacanya untuk terlibat dalam aktivitas seksual.

Hasil penelitian ini sejalan dengan penelitian yang dilakukan penelitian yang dilakukan pada remaja di Pekanbaru menunjukkan adanya hubungan yang bermakna antara frekuensi keterpaparan pornografi terhadap perilaku seksual remaja ( $p$-value $=0,000$ ) (Yutifa et al., 2015).

Sejalan dengan penelitian Supriati dan Fikawati (2009) menyatakan remaja yang mempunyai frekuensi paparan pornografi sering
(>1 kali seminggu) berisiko lima kali mengalami efek paparan dibandingakan dengan remaja yang frekuensi paparan jarang (<1 kali seminggu). Hal ini dapat disimpulkan bahwa remaja yang terpapar pornografi lebih beresiko berperilaku seksual berisiko dibandingkan dengan remaja yang tidak terpapar pornografi. Makin meningkatnya remaja yang terpapar pornografi merupakan suatu masalah besar yang berkontribusi terhadap meningkatnya jumlah remaja yang berperilaku seksual aktif. Dengan demikian perilaku seksual aktif ini akan mendorong remaja untuk melakukan hubungan seksual pranikah yang salah satu dampaknya kehamilan tidak diinginkan pada remaja.

Sesuai Social Learning Theory, pornografi dapat mempengaruhi hasrat seksual remaja dan remaja dapat belajar tentang seksualitas dari observasi yang digambarkan oleh berbagai media (Supriati \& Fikawati, 2009). Pornografi dapat menghasilkan rangsangan fisiologis dan emosional (pengaktifan sistem syaraf sebagai lawan rangsangan seksual), dan peningkatan tingkat rangsangan kemungkinan akan menghasilkan beberapa bentul perilaku seksual berisiko (Wallmyr \& Welin, 2006).

Pendidikan remaja yang mengalami kehamilan mayoritas berpendidikan dasar (Diagram 4). Hasil uji chi-square dengan tingkat kepercayaan $95 \%$, diperoleh hasil $p=0,000$ sehingga menyatakan bahwa pendidikan memiliki hubungan dengan kejadian kehamilan remaja yang terjadi di Indonesia. Hal ini sesuai dengan penelitian yang di lakukan di 5 kota yaitu Baltimore, Johannesburg, Ibadan, Delhi dan Shanghai menyebutkan bahwasannya pendidikan memiliki kaitan erat dengan kehamilan remaja, remaja 


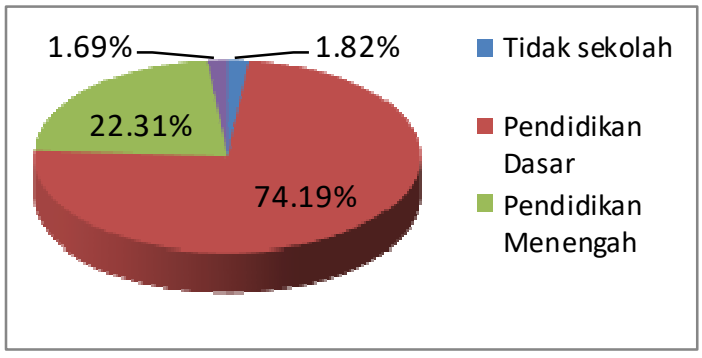

Diagram 4. Pendidikan Terakhir Kehamilan Remaja

yang mendapatkan pendidikan di bangku sekolah cenderung lebih rendah untuk mengalami kehamilan remaja. Studi yang telah dilakukan menunjukkan bahwa anak perempuan yang bersekolah, kecil kemungkinannya untuk melakukan aktivitas seksual dan apabila mereka melakukan hubungan seksual, mereka lebih cenderung menggunakan kontrasepsi (Brahmbhatt et al., 2014). Faisal-Cury et al. (2017) juga menyatakan bahwa pendidikan yang rendah memiliki risiko dua kali lebih besar untuk hamil.

Rendahnya pendidikan membuat kurangnya pengetahuan sehingga akan mempengaruhi pengambilan keputusan untuk melakukan pernikahan dini tanpa mengetahui akibat yang ditimbulkan dari pernikahan dini tersebut (Realita \& Meiranny, 2018). Pengetahuan seksual yang salah dapat melahirkan persepsi yang salah tentang seksualitas dan selanjutnya akan mendorong perilaku seksual yang salah dengan segala akibatnya (Ismarwati \& Utami, 2017).

\section{Kesimpulan}

Kehamilan remaja di Indonesia dipengaruhi oleh berbagai faktor. Pada penelitian ini menunjukkan bahwasannya paparan media informasi dan juga tingkat pendidikan memiliki kontribusi akan kejadian kehalilan pada remaja.
Media informasi memiliki kontribusi yang cukup besar dalam mengenalkan konten seksual kepada remaja. Baik melalui film, game, dan gambar-gambar yang memiliki muatan pornografi. Selain itu di televisi pun banyak disiarkan sinetron yang mampu menjurumuskan para remaja akan kegiatan-kegiatan negatif. Tontonan semacam inilah yang mampu menyebabkan rasa penasaran pada diri remaja untuk mencoba melakukan yang berbau seksualitas, mulai dari pelukan, saling mencium hingga melakukan intercourse.

Disebabkan oleh berbagai informasi yang mampu diakses dan diterima para remaja memalui media informasi diperlukan tameng yang baik agar mempu menjaga remaja dari berbagai kegiatan negatif.

Selain papran dari media informasi, tingkat pendidikan juga mempengaruhi akan kejadian kehamilan pada remaja. Apabila remaja memiliki pendidikan yang bagus, maka para remaja menerima pendidikan yang memiliki muatan moral, agama bahkan pendidikan reproduksi. Sehingga mampu memberikan pemahaman kepada remaja akan konsekunsi melakukan hubungan seksual di luar ikatan pernikahan.

Dari temuan di atas untuk menekan kejadian kehamilan remaja tenaga kesehatan dapat 
berinisiatif untuk mengubah kebijakan yang bertujuan mengubah perilaku berisiko seksual di kalangan remaja, termasuk peningkatan pendidikan seksual di sekolah, peran terpenting tenaga kesehatan adalah memberikan informasi dan layanan kesehatan seksual yang sesuai dalam praktik mereka jika mereka memberikan layanan klinis kepada kaum muda. Tenaga kesehatan harus mengenali kenyataan aktivitas seksual remaja. Studi telah menunjukkan bahwa, pada akhir sekolah menengah, sebagian besar remaja telah melakukan hubungan seksual, dan sekitar $10 \%$ telah melakukan hubungan intim sebelum usia 15 tahun. Sebagai bagian dari pemeriksaan umum mengenai kesejahteraan remaja, petugas kesehatan harus meminta keterangan kepada setiap remaja tentang aktivitas seksual mereka, seperti penggunaan kondom dan kontrasepsi, riwayat infeksi menular seksual dan kehamilan, dan kebutuhan akan informasi tentang masalah kesehatan seksual lainnya (Langille, 2007).

Kementerian Kesehatan sebagai leading sector dalam pelayanan kesehatan remaja telah berupaya memberikan perhatian terhadap masalah remaja seperti remaja berbasis sekolah dengan mendapat pelayanan kesehatan melalui UKS. Upaya lain adalah dengan pengembangan puskesmas sehingga menjadi peduli akan kebutuhan remaja melalui Pelayanan Kesehatan Peduli Remaja (PKPR) (Sari, 2016).[]

\section{Daftar Pustaka}

Badan Kependudukan dan Keluarga Berencana Nasional, Badan Pusat Statistik, Kementerian Kesehatan, Measure DHS, ICF International.
(2013). Sunvei demografi dan kesehatan Indonesia 2012 (SDKI12).

BKKBN. (2016). Survei indikator kinerja program kependudukan, Keluarga Berencana dan pembangunan keluarga, Rencana Pembangunan Jangka Menengah Nasional (RPJMN).

Brahmbhatt, H., Kågesten, A., Emerson, M., Decker, M. R., Olumide, A. O., Ojengbede, O., Lou, C., Sonenstein, F. L., Blum, R. W., \& DelanyMoretlwe, S. (2014). Prevalence and determinants of adolescent pregnancy in urban disadvantaged settings across five cities. Journal of Adolescent Health, 55(6), S48-S57. https://doi.org/10.1016/j.jadohealth.2014.07. 023

Delgado, H. M., \& Austin, S. B. (2007). Can media promote responsible sexual behaviors among adolescents and young adults? Current Opinion in Pediatrics, 19(4), 405-410. https:// doi.org/10.1097/MOP.0b013e32823ed008

Faisal-Cury, A., Tabb, K., Niciunovas, G., Cunningham, C., Menezes, P., \& Huang, H. (2017). Lower education among low-income Brazilian adolescent females is associated with planned pregnancies. International Journal of Women's Health, 9, 43-48. https://doi.org/ 10.2147/IJWH.S118911

Gallup-Black, A., \& Weitzman, B. C. (2004). Teen pregnancy and urban youth: Competing truths, complacency, and perceptions of the problem. Journal of Adolescent Health, 34(5), 366-375.https://doi.org/10.1016/ j.jadohealth.2003.09.010

Gökçe, B., Özşahin, A., \& Zencir, M. (2007). Determinants of adolescent pregnancy in an urban area in Turkey: A population-based case-control study. Journal of Biosocial Science, 39(2), 301-311. https://doi.org/ 10.1017/\$0021932006001763 
Honig, A. S. (2012). Teen pregnancy. International Journal of Adolescence and Youth, 17(4), 181187. https://doi.org/10.1080/02673843. 2012.655912

Huver, R. M. E., Otten, R., de Vries, H., \& Engels, R. C. M. E. (2010). Personality and parenting style in parents of adolescents. Journal of Adolescence, 33(3), 395-402. https://doi.org/ 10.1016/j.adolescence.2009.07.012

Ismarwati, I., \& Utami, I. (2017). Faktor faktor yang mempengaruhi kejadian kehamilan tidak diinginkan pada remaja. Journal of Health Studies, 1(2), 168-177. https://doi.org/ 10.31101/jhes.336

Langille, D. B. (2007). Teenage pregnancy: Trends, contributing factors and the physician's role. Canadian Medical Association Journal, 176(11), 1601-1602. https://doi.org/10.1503/ cmaj.070352

Nugraha, B. D. (2010). It"s about A-Z tentang sex. Jakarta: Bumi Aksara.

Omarsari, S. D., \& Djuwita, R. (2008). Kehamilan pranikah remaja di Kabupaten Sumedang. Kesmas: National Public Health Journal, 3(2), 57-64.

https://doi.org/10.21109/kesmas.v3i2.230

Raj, A. D., Rabi, B., Amudha, P., Edwin-R, van T., \& Glyn, C. (2010). Factors associated with teenage pregnancy in south asia: A systematic review. Health Science Journal, 4(1), 13-14.

Rohman, A. (2011). Memahami pendidikan dan ilmu pendidikan. Yogyakarta: LaksBang Mediatama.

Sámano, R., Martínez-Rojano, H., Robichaux, D., Rodríguez-Ventura, A. L., Sánchez-Jiménez, B., de la Luz Hoyuela, M., Godínez, E., \& Segovia, S. (2017). Family context and individual situation of teens before, during and after pregnancy in Mexico City. BMC Pregnancy and Childbirth, 17(1), 382. https://doi.org/ 10.1186/s12884-017-1570-7

Sari, D. (2016). Faktor-faktor yang berhubungan dengan kehamilan pada usia remaja di Puskesmas Ciputat Kota Tangerang Selatan tahun 2014. Arkemas: Arsip Kesehatan Masyarakat, 1(1), 4-17.

Sayem, A. M., \& Nury, A. T. M. S. (2011). Factors associated with teenage marital pregnancy among Bangladeshi women. Reproductive Health, 8, 16. https://doi.org/10.1186/17424755-8-16

Supriati, E., \& Fikawati, S. (2009). Effect of pornography exposure on Junior High School teenagers of Pontianak in 2008. Makara: Human Behavior Studies in Asia, 13(1), 48-56. https://doi.org/10.7454/mssh.v13i1.210

Wallmyr, G., \& Welin, C. (2006). Young people, pornography, and sexuality: Sources and attitudes. The Journal of School Nursing, 22(5), 290-295.

https://doi.org/10.1177/1059840506022005 0801

Weiss, J. A. (2012). Who will listen? Rural teen pregnancy reflections. The Journal for Nurse Practitioners, 8(10), 804-809. https://doi.org/ 10.1016/j.nurpra.2012.02.028

WHO. (2014). Adolescent pregnancy.

Wijayanti. (2014). Resiko kehamilan pada usia remaja. Profesi: Media Publikasi Penelitian, 10(1), 44-46. https://doi.org/10.26576/ profesi.64

Yutifa, H., Dewi, A. P., \& Misrawati, M. (2015). Hubungan paparan pornografi melalui elektronik terhadap perilaku seksual remaja. Jurnal Online Mahasiswa (JOM) Bidang IImu Keperawatan, 2(2), 1141-1148. 